\title{
Determinants of Community Interest in Batang Toru District Using Cicil Gold Products at PT. Bank Sharia Mandiri Kcp Batang Toru
}

\author{
Ika Purnama ${ }^{1}$, Nofinawati ${ }^{2}$, Sarmiana $^{3}$, Ferri Alfadri ${ }^{4}$ \\ ${ }^{1}$ IAIN Padangsidimpuan (Perbankan Syariah, FEBI, IAIN Padangsidimpuan) \\ ${ }^{2}$ IAIN Padangsidimpuan (Perbankan Syariah, FEBI, IAIN Padangsidimpuan) \\ ${ }^{3}$ IAIN Padangsidimpuan (Perbankan Syariah, FEBI, IAIN Padangsidimpuan) \\ ${ }^{4}$ IAIN Padangsidimpuan (Perbankan Syariah, FEBI, IAIN Padangsidimpuan) \\ purnama@gmail.com ${ }^{1}$, Nofinawati@iain-padangsidimpuan.ac.id ${ }^{2}$, Sarmiana@iain-padangsidimpuan.ac.id ${ }^{3}$, \\ Ferrialfadri@iain-padangsidimpuan.ac.id ${ }^{4}$
}

\begin{abstract}
ABSTRAK
Kurangnya minat masyarakat Kecamatan Batang Toru dalam menggunakan produk cicil emas. Kenaikan harga emas membuat sebagian masyarakat cenderung ingin memiliki emas. Hal ini menyebabkan minat masyarakat untuk miliki emas juga mengalami kenaikan. Produk cicil emas menarik perhatian masyarakat untuk memiliki emas. Namun, yang terjadi pada masyarakat Kecamatan Batang Toru mereka merasa terbebani dengan uang muka yang diberikan pihak bank kepada masyarakat yaitu sebesar $20 \%$, sehinggga masyarakat lebih memilih mencicil emas dengan cara yang muda bersifat konvensional dibandingkan dengan yang bersifat syariah. Tujuan penelitian ini untuk mengetahui apakah promosi, harga, dan kualitas pelayanan berpengaruh terhadap minat masyarakat Kecamatan Batang Toru menggunakan produk cicil emas di PT. Bank Syariah Mandiri KCP Batang Toru. Teori yang digunakan dalam penelitian ini adalah minat masyarakat, teori promosi, harga, kualitas pelayanan. Penelitian ini merupakan penelitian kuantitatif dengan menggunakan anilisis uji regresi berganda, teknik pengumpulan data menggunakan angket dengan jumlah sampel 100 masyarakat Kecamatan Batang Toru. Teknik pengambilan sampel dengan samplinginsidential. Pengolahan data dilakukan dengan spss versi 23. Hasil analisis yang dilakukan peneliti, Hasil penelitian secara parsial ( $\mathrm{ji}$ t) menunjukan bahwa promosi berpengaruh terhadap minat masyarakat Kecamatan Batang Toru menggunakan produk cicil emas di PT. Bank Syariah Mandiri KCP Batang Toru. Harga berpengaruh terhadap minat masyarakat Kecamatan Batang Toru menggunakan produk cicil emas di PT. Bank Syariah Mandiri KCP Batang Toru. Dan Kualitas pelayanan berpengaruh terhadap minat masyarakat Kecamatan Batang Toru menggunakan produk cicil emas di PT. Bank Syariah Mandiri KCP Batang Toru. Dilihat dengan uji $\mathrm{F}$ promosi, harga dan kualitas pelayanan berpengaruh secara simultan terhadap minat masyarakat Kecamatan Batang Toru menggunakan produk cicil emas di PT. Bank Syariah Mandiri KCP Batang Toru.
\end{abstract}

Kata Kunci: Harga, Kualitas Pelayanan, Minat Masyarakat, Promosi

\section{ABSTRACT}

The lack of interest of the people of Batang Toru District in using gold installment products. The increase in gold prices makes some people tend to want to own gold. This causes people's interest to own gold to also increase. Gold installment products attract people's attention to own gold. However, what happened to the people of Batang Toru Subdistrict they felt burdened with the down payment given by the bank to the community, 
which was $20 \%$, so that the community preferred to pay in installments for gold in a conventional way compared to sharia. The purpose of this study is to determine whether promotion, price, and service quality affect the interest of the people of Batang Toru District using gold installment products at PT. Bank Syariah Mandiri KCP Batang Toru. The theory used in this research is public interest, promotion theory, price, service quality. This study is a quantitative study using multiple regression analysis, data collection techniques using a questionnaire with a sample of 100 people in Batang Toru District. The sampling technique is incidental sampling. Data processing was carried out with SPSS version 23 . The results of the analysis carried out by researchers, the results of the partial study ( $t$ test) showed that promotion had an effect on the interest of the people of Batang Toru District using gold installment products at PT. Bank Syariah Mandiri KCP Batang Toru. Price has an effect on the interest of the people of Batang Toru District using gold installment products at PT. Bank Syariah Mandiri KCP Batang Toru. And the quality of service has an effect on the interest of the people of Batang Toru District using gold installment products at PT. Bank Syariah Mandiri KCP Batang Toru. Judging by the promotion $\mathrm{F}$ test, price and quality of service have a simultaneous effect on the interest of the people of Batang Toru District using gold installment products at PT. Bank Syariah Mandiri KCP Batang Toru.

Keywords: Price, Service Quality, Public Interest, Promotion

\section{A. PENDAHULUAN}

Kenaikan harga emas membuat

sebagian masyarakat cenderung ingin memiliki

emas, dan sebagian masyarakat lainnya tidak

ingin memiliki emas karena terbebani dengan

harganya yang cukup mahal. kemudian

dimanfaatkan oleh pihak Bank Syariah Mandiri

untuk menjawab kebutuhan masyarakat akan

produk investasi. Salah satu produk yang

dikeluarkan Bank Syariah Mandiri KCP Batang

Toru adalah produk cicil emas. Hal ini

menyebabkan minat masyarakat untuk memiliki

emas juga mengalami kenaikan. Namun, yang

terjadi pada masyarakat Kecamatan Batang
Toru mereka merasa terbebani dengan uang

muka yang diberikan pihak bank kepada

masyarakat yaitu sebesar 20\%, sehinggga

masyarakat lebih memilih mencicil emas

dengan cara yang muda bersifat konvensional

dibandingkan dengan yang bersifat

syariah.(Jakpar hakim Account Maintenance PT.

Bank Syariah Mandiri KCP Batang Toru, 11

Oktober 2020)

Berdasarkan pengamatan peneliti

sewaktu magang di Bank Syariah Mandiri KCP

Batang Toru tahun 2019, masyarakat

Kecamatan Batang Toru kurang berminat

menggunakan produk cicil emas. Hal ini dapat 
dibuktikan peneliti dari hasil wawancara dengan Bapak Abdul Azis sebagai Micro Financing Analyst yang menyatakan bawah jumlah data nasabah produk cicil emas sebanyak 56 nasabah ditahun 2019.(Abdul Azis Micro Financing Analyst PT. Bank Syariah Mandiri KCP Batang Toru, 10 Oktober 2019)

Tabel 1

Jumlah Nasabah Produk Cicil Emas di PT. Bank

Syariah Mandiri

KCP Batang Toru

\begin{tabular}{|c|c|}
\hline \multicolumn{2}{|c|}{ Produk Cicil Emas } \\
\hline Tahun & Jumlah Nasabah \\
\hline 2017 & 43 Nasabah \\
\hline 2018 & 50 Nasabah \\
\hline 2019 & 56 Nasabah \\
\hline
\end{tabular}

Sumber: Bank Syariah Mandiri KCP Batang Toru

Tabel 1 diperoleh jumlah nasabah produk cicil emas dipersentasikan dari tahun 2017 sampai 2018 mengalami kenaikkan sebesar 14 \% sedangkan pada tahun 2018 sampai 2019 mengalami kenaikan sebesar 11\%. Maka dapat disimpulkan bahwa persentasi minat masyarakat kecamatan batang toru dalam menggunakan produk cicil emas mengalami penurunan dari tahun 2017 sampai 2019.
Minat pada seseorang akan suatu objek atau hal tertentu tidak akan muncul dengan sendirinya secara tiba-tiba dalam diri individu. Minat dapat timbul pada diri seseorang melalui proses. Dengan adanya perhatian dengan interaksi dengan lingkungan maka minat tersebut dapat berkembang.(Fahmi Gunawan, 2018:5) Namun, Promosi yang dilakukan Bank Syariah Mandiri KCP Batang Toru mengenai produk cicil emas sangat kurang, sehingga dapat menyebabkan banyaknya masyarakat yang tidak mengetahui produk cicil emas di bank tersebut, yang berakibat terjadi kurangnya minat masyarakat terhadap produk cicil emas. Padahal promosi dapat dikatakan sebagai faktor penentu bagi minat masyarakat. (Nana Herdiana Abdurrahman, 2013:349) Promosi adalah cara mengkomunikasikan barang atau jasa yang ditawarkan supaya konsumen mengenal dan membeli. (Budi Gautama Siregar, 2018: 185).

Hal awal yang diperhatikan oleh calon konsumen adalah harga. Dalam penetapan harga produk harus sesuai dan wajar dengan kualitas produk yang ditawarkan. Harga yang terlalu tinggi akan membuat konsumen pindah ke produk lain yang sejenis tetapi dengan harga yang lebih murah, begitu sebaliknya.(Ruri Putri Utami. Dkk, 2017:44) Tidak hanya promosi dan harga yang dapat 
Purnama ${ }^{1}$, Nofinawati ${ }^{2}$, Sarmiana ${ }^{3}$, Ferri Alfadri ${ }^{4}$

menarik minat masyarakat dalam membeli

barang. Kualitas pelayanan adalah tingkat

keunggulan yang diharapkan dan pengendalian

atas tingkat keunggulan tersebut untuk

memenuhi keinginan pelanggan.(Nurul Huda,

2017:139) Kualitas pelayanan juga menjadi

salah satu penentu dalam menarik minat

masyarakat dalam membeli barang atau jasa.

Kualitas pelayanan yang baik akan mampu

menarik masyarakat untuk melakukan

pembelian produk. Ketika suatu bank

mempertahankan pelayanannya maka akan

mampu menjaga nasabah mereka agar tidak

membeli produk lain dan akan menimbulkan

loyalitas nasabah kepada bank tersebut.

\section{B. METODE}

Lokasi penelitian yang dilakukan peneliti bertempat di PT. Bank Syariah Mandiri KCP Batang Toru, yang beralamat di Jl. Merdeka No 47, Kel. Wek II Kecamatan Batang Toru Kabupaten Tapanuli Selatan, Sumatera Utara. Waktu penelitian ini dilakukan mulai Oktober 2020 sampai April 2021. Jenis penelitian ini adalah penelitian kuantitatif dengan pendekatan deskriptif. Penelitian kuantitatif
POINT Vol. 2, No. 2, Des 2021 deskriptif adalah penelitian yang berusaha menggambarkan fenomena yang terjadi secara nyata, realitas, aktual pada saat ini.(Ajat Rukajat, 2018:1).

Populasi adalah wilayah generalisasi yang terdiri atas obyek/subyek yang mempunyai kualitas dan karakteristik tertentu yang ditetapkan oleh peneliti untuk dipelajari dan kemudian ditarik kesimpulannya.(Sugiyono, 2016:80) Populasi dalam penelitian ini adalah masyarakat kecamatan batang toru yang berjumlah 7.484 rumah tangga. Sampel adalah sebagian dari subjek dalam populasi yang diteliti yang sudah tentu mampu secara representatif dapat mewakili seluruh populasinya. Dalam penelitian ini menggunakan teknik pengambilan sampel adalah sampling insidential. (Suryani, Hendryadi, 2015:201) Pengambilan sampel pada penelitian ini menggunakan rumus Taro Yamane dengan tingkat kesalahan $10 \%$. sampel pada penelitian ini adalah minimal 99 responden.

\section{HASIL DAN PEMBAHASAN}

Hasil Uji Validitas 
Adapun $r_{\text {hitung }}$ untuk tiap item bisa dilihat pada kolom pearson correlation, sedangkan $r_{\text {tabel }}$ menggunakan taraf signifikansi 0,1 dengan derajat kebebasan $(\mathrm{df})=\mathrm{n}$ (jumlah sampel) -2 jadi df = $100-2=98$, maka diperoleh $r_{\text {tabel }}=0,1654$. Hasil uji validitas variabel promosi sebagai berikut:

Tabel 2

Hasil Uji Validitas Promosi (X1)

\begin{tabular}{|c|c|c|c|}
\hline $\begin{array}{c}\text { Item } \\
\text { Pernyataan }\end{array}$ & $r_{\text {hitung }}$ & $r_{\text {tabel }}$ & Keterangan \\
\hline X.1 & 0,794 & \multirow{7}{*}{$\begin{array}{c}\text { Instrumen } \\
\text { valid, jika } \\
\text { rhitung>rtabel } \\
\text { dengan } \mathrm{df}=\mathrm{n} \\
-2=100-2= \\
98 \text { pada taraf } \\
\text { signifikan } 10 \% \\
\text { sehingga } \\
\text { diperoleh } \\
\text { rtabel = } \\
0,1654 .\end{array}$} & Valid \\
\hline$X .2$ & 0,848 & & Valid \\
\hline X.3 & 0,448 & & Valid \\
\hline X.4 & 0,833 & & Valid \\
\hline X.5 & 0,400 & & Valid \\
\hline X.6 & 0,436 & & Valid \\
\hline X.7 & 0,762 & & Valid \\
\hline
\end{tabular}

Sumber: Data diolah, SPSS 23 Tahun 2021

Hasil tabel 2Uji validitas diatas menunjukkan bahwa nilai item pernyataan 1,2 , 3, 4, 5, 6, 7 dan 8 menunjukkan nilai rhitung lebih besar dari rtabel sehingga item-item pernyataan tersebut dikatakan valid. Adapun hasil uji validitas variabel harga sebagai berikut :

Tabel 3

Hasil Uji Validitas Harga (X2)

\begin{tabular}{|c|c|c|c|}
\hline $\begin{array}{c}\text { Item } \\
\text { Pernyataan }\end{array}$ & $\mathrm{r}_{\text {hitung }}$ & $\mathrm{r}_{\text {tabel }}$ & $\begin{array}{c}\text { Ketera } \\
\text { ngan }\end{array}$ \\
\hline $\mathrm{X.1}$ & & $\begin{array}{c}\text { Instrumen } \\
\text { valid, jika } \\
\text { rhitung> } \\
\text { rtabel } \\
\text { dengan df }=\end{array}$ & \\
\hline & & & \\
\hline
\end{tabular}

\begin{tabular}{|c|c|c|c|}
\hline & & \multirow{8}{*}{$\begin{array}{c}n-2=100-2 \\
=98 \text { pada } \\
\text { taraf } \\
\text { signifikan } \\
10 \% \\
\text { sehingga } \\
\text { diperoleh } \\
\text { rtabel = } \\
0,1654\end{array}$} & \\
\hline X.2 & 0,878 & & Valid \\
\hline X.3 & 0,798 & & Valid \\
\hline X.4 & 0,861 & & Valid \\
\hline$X .5$ & 0,878 & & Valid \\
\hline X.6 & 0,530 & & Valid \\
\hline X.7 & 0,776 & & Valid \\
\hline$X .8$ & 0,840 & & Valid \\
\hline
\end{tabular}

Sumber: Data diolah, SPSS 23 Tahun 2021

Hasil tabel 3 uji validitas diatas menunjukkan bahwa nilai item pernyataan 1,2 , 3, 4, 5, 6, 7dan 8, menunjukkan nilai rhitung lebih besar dari rtabel sehingga item-item pernyataan tersebut dikatakan valid. Adapun hasil uji validitas variabel kualitas pelayanan sebagai berikut:

Tabel 4

Hasil Uji Validitas Kualitas Pelayanan (X3)

\begin{tabular}{|c|c|c|c|}
\hline $\begin{array}{c}\text { Item } \\
\text { Pernyataan }\end{array}$ & $r_{\text {hitung }}$ & $r_{\text {tabel }}$ & Keterangan \\
\hline X.1 & 0,709 & \multirow{10}{*}{$\begin{array}{l}\text { nstrumen } \\
\text { valid, jika } \\
\text { rhitung> } \\
\text { rtabel } \\
\text { dengan df } \\
=\mathrm{n}-2= \\
100-2= \\
98 \text { pada } \\
\text { taraf } \\
\text { signifikan } \\
10 \% \\
\text { sehingga } \\
\text { diperoleh } \\
\text { rtabel = } \\
0,1654\end{array}$} & Valid \\
\hline $\mathrm{X} .2$ & 0,758 & & Valid \\
\hline X.3 & 0,579 & & Valid \\
\hline X.4 & 0,631 & & Valid \\
\hline$X .5$ & 0,758 & & Valid \\
\hline X.6 & 0,630 & & Valid \\
\hline X.7 & 0,335 & & Valid \\
\hline X.8 & 0,630 & & Valid \\
\hline X.9 & 0,709 & & Valid \\
\hline X.10 & 0,631 & & Valid \\
\hline
\end{tabular}

Sumber: Data diolah, SPSS 23 Tahun 2021 
Hasil tabel 4 Uji validitas di atas menunjukkan bahwa nilai item pernyataan 1,2 , $3,4,5,6,7,8,9$ dan 10 menunjukkan nilai rhitung lebih besar dari rtabel sehingga itemitem pernyataan tersebut dikatakan valid. Adapun hasil uji validitas minat masyarakat sebagai berikut:

Tabel 5

Hasil Uji Validitas Minat Masyarakat (Y)

\begin{tabular}{|c|c|c|c|}
\hline $\begin{array}{c}\text { Item } \\
\text { Pernyataan }\end{array}$ & $r_{\text {hitung }}$ & $r_{\text {tabel }}$ & Keterangan \\
\hline $\mathrm{Y} .1$ & 0,617 & \multirow{10}{*}{$\begin{array}{l}\text { Instrumen } \\
\text { valid, jika } \\
\text { rhitung> } \\
\text { rtabel } \\
\text { dengan df } \\
=\mathrm{n} 2= \\
100-2= \\
98 \text { pada } \\
\text { taraf } \\
\text { signifikan } \\
10 \% \\
\text { sehingga } \\
\text { diperoleh } \\
\text { rtabel = } \\
0,1654\end{array}$} & Valid \\
\hline Y.2 & 0,561 & & Valid \\
\hline Y.3 & 0,592 & & Valid \\
\hline Y.4 & 0,390 & & Valid \\
\hline Y.5 & 0,607 & & Valid \\
\hline Y.6 & 0,559 & & Valid \\
\hline Y.7 & 0,523 & & Valid \\
\hline Y.8 & 0,390 & & Valid \\
\hline Y.9 & 0,488 & & Valid \\
\hline Y.10 & 0,607 & & Valid \\
\hline
\end{tabular}

Sumber: Data diolah, SPSS 23 Tahun 2021

Hasil tabel 5 Uji validitas di atas menunjukkan bahwa nilai item pernyataan 1,2 , $3,4,5,6,7,8,9$ dan 10 menunjukkan nilai rhitung lebih besar dari rtabel sehingga itemitem pernyataan tersebut dikatakan valid. Jadi dapat disimpulkan bahwa hasil uji validitas dari keseluruhan item pernyataan variabel promosi,
POINT Vol. 2, No. 2, Des 2021 harga, kualitas pelayanan dan minat masyarakat dinyatakan valid.

\section{Hasil Uji Reliabilitas}

Uji reliabilitas dilakukan dengan menghitung Cronbach's Alpha > 0,60 maka dapat dikatakan reliable. Adapun hasil uji reliabilitas dapat dilihat pada tabel sebagai berikut:

Tabel 6 Hasil Uji Reliabilitas

\begin{tabular}{|c|r|r|}
\hline \multicolumn{3}{|c|}{ Reliability Statistics } \\
\hline Variabel & $\begin{array}{c}\text { Cronbach's } \\
\text { Alpha }\end{array}$ & $\begin{array}{c}\text { N Of } \\
\text { Items }\end{array}$ \\
\hline Promosi & .801 & 8 \\
\hline Harga & .894 & 8 \\
\hline $\begin{array}{c}\text { Kualitas } \\
\text { Pelayanan }\end{array}$ & .839 & 10 \\
\hline $\begin{array}{c}\text { Minat } \\
\text { Masyarakat }\end{array}$ & .705 & 10 \\
\hline
\end{tabular}

Sumber: Data diolah, SPSS 23 Tahun 2021

Berdasarkan hasil-hasil tabel $6 \quad$ Uji reliabilitas di atas menunjukkan bahwa nilai Cronbach's Alpha promosi yaitu 0,801> 0,60 . Harga yaitu $0,894>0,60$. Kualitas pelayanan yaitu $0,839>0,60$. Minat masyarakat yaitu $0,705>0,60$. Dengan demikian variabel promosi, harga kualitas pelayanan dan minat masyarakat dikatakan reliable. 
Hasil Uji Normalitas

Hasil uji normalitas dengan metode One-Sample Kolmogorov-Smirnov sebagai berikut:

Tabel 7

Hasil Uji Normalitas

One-Sample Kolmogorov-Smirnov Test

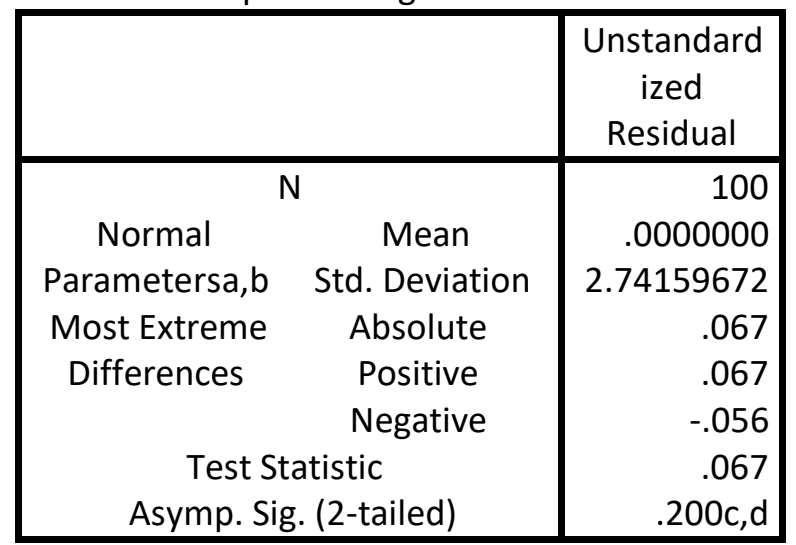

Sumber: Data diolah, SPSS 23 Tahun 2021

Berdasarkan tabel 7 diatas dapat dilihat

bahwa hasil uji normalitas dengan metode One-

Sample Kolmogorov-Smirnov Test menunjukkan

nilai signifikan (Asymp. Sig. 2-tailed) sebesar

0,200>0,1 maka dapat disimpulkan bahwa

model regresi telah memenuhi normalitas,

artinya variabel berdistribusi normal.

Hasil Uji linearitas

Hasil uji linearitas promosi terhadap

minat masyarakat sebagai berikut :

Tabel 8

Hasil Uji Linearitas Promosi

Terhadap Minat Masyarakat

\begin{tabular}{|ccc|r|r|r|r|r|}
\hline $\begin{array}{c}\text { Masyara } \\
\text { kat }{ }^{*} \\
\text { Promosi }\end{array}$ & $\begin{array}{c}\mathrm{n} \\
\text { Group } \\
\mathrm{s}\end{array}$ & $\begin{array}{c}\text { Linearity } \\
\text { Deviation } \\
\text { from } \\
\text { Linearity }\end{array}$ & 168.103 & 9 & 18.678 & 1.821 & .075 \\
\cline { 2 - 7 } & Within Groups & 912.921 & 89 & 10.258 & & \\
\hline & Total & 1317.390 & 99 & & & \\
\hline
\end{tabular}

Sumber: Data diolah, SPSS 23 Tahun 2021

Hasil uji linearitas variabel promosi

terhadap minat masyarakat pada tabel 8

diperoleh nilai tarif signifikan pada linearitas

sebesar 0,000 . Sehingga $0,000<0,1$. Dapat

disimpulkan terdapat hubungan yang linear

antara variabel promosi terhadap minat

masyarakat. Adapun hasil uji linearitas harga

terhadap minat masyarakat sebagai berikut :

Tabel 9

Hasil Uji Linearitas Harga

Terhadap Minat Masyarakat

\begin{tabular}{|c|c|c|c|c|c|c|c|}
\hline \multicolumn{8}{|c|}{ ANOVA Table } \\
\hline & & & $\begin{array}{l}\text { Sum of } \\
\text { Squares }\end{array}$ & Df & hean Square & $\mathrm{F}$ & Sig. \\
\hline \multirow{5}{*}{$\begin{array}{c}\text { Minat } \\
\text { Masyara } \\
\text { kat * } \\
\text { Harga }\end{array}$} & $\begin{array}{r}\text { Betw } \\
\text { een }\end{array}$ & (Combined & 122.530 & 9 & 13.614 & 1.025 & .426 \\
\hline & Gro & Linearity & 56.159 & 1 & 56.159 & 4.230 & .043 \\
\hline & ups & $\begin{array}{c}\text { Deviation } \\
\text { from } \\
\text { Linearity }\end{array}$ & 66.371 & 8 & 8.296 & 625 & .755 \\
\hline & $\mathrm{Wi}$ & hin Groups & 1194.860 & 90 & 13.276 & & \\
\hline & & Total & $\begin{array}{r}1317.39 \\
0\end{array}$ & 99 & & & \\
\hline
\end{tabular}

Sumber: Data diolah, SPSS 23 Tahun 2021

Hasil uji linearitas variabel harga

terhadap minat masyarakat pada tabel 9 diperoleh nilai tarif signifikan pada linearitas sebesar 0,000. Sehingga 0,043<0,1. Dapat disimpulkan terdapat hubungan yang linear

\begin{tabular}{|c|c|c|c|c|c|}
\hline & $\begin{array}{l}\text { Sum of } \\
\text { Squares }\end{array}$ & Df & $\begin{array}{l}\text { Mean } \\
\text { Square }\end{array}$ & $\mathrm{F}$ & dificara \\
\hline Minat $\quad$ Betwee (Combined) & 404.469 & 10 & 40.447 & 3.943 & .000 \\
\hline
\end{tabular}


Purnama ${ }^{1}$, Nofinawati ${ }^{2}$, Sarmiana ${ }^{3}$, Ferri Alfadri ${ }^{4}$

masyarakat. Adapun hasil uji linearitas kualitas pelayanan terhadap minat masyarakat sebagai berikut :

Tabel 10

Hasil Uji Linearitas Kualitas Pelayanan Terhadap Minat Masyarakat ANOVA Table

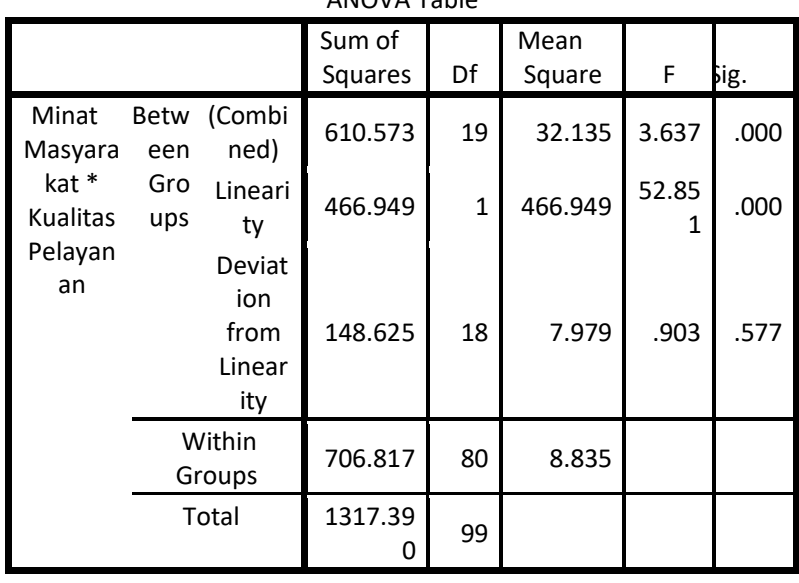

Sumber: Data diolah, SPSS 23 Tahun 2021

Hasil uji linearitas variabel kualitas

pelayanan terhadap minat masyarakat pada

tabel 10 diperoleh nilai tarif signifikan pada

linearitas sebesar 0,000. Sehingga 0,000 0,1.

Dapat disimpulkan terdapat hubungan yang

linear antara variabel kualitas pelayanan

terhadap minat masyarakat.

Hasil Uji Multikolinieritas

Hasil uji multikolinearitas dalam

penelitian ini dapat dilihat pada tabel sebagai

berikut:

Tabel 11

Hasil Uji Multikolinearitas

Coefficientsa

\begin{tabular}{|c|c|c|c|c|c|}
\hline \multicolumn{6}{|c|}{ Coefficientsa } \\
\hline Model & $\begin{array}{l}\text { Unstandardized } \\
\text { Coefficients }\end{array}$ & $\begin{array}{c}\text { Standar } \\
\text { dized } \\
\text { Coefficie } \\
\text { nts }\end{array}$ & $\mathrm{T}$ & Sig. & $\begin{array}{c}\text { Collinearity } \\
\text { Statistics }\end{array}$ \\
\hline
\end{tabular}
0,1 .

POINT Vol. 2, No. 2, Des 2021

\begin{tabular}{|c|c|c|c|c|c|c|c|}
\hline & B & $\begin{array}{l}\text { Std. } \\
\text { Error }\end{array}$ & Beta & & & Tolerance & VIF \\
\hline $\begin{array}{c}1 \text { (Const } \\
\text { ant) }\end{array}$ & 11.653 & 3.834 & & $\begin{array}{r}3.03 \\
9\end{array}$ & .003 & & \\
\hline $\begin{array}{c}\text { Promo } \\
\mathrm{si}\end{array}$ & .551 & .157 & .448 & $\begin{array}{r}3.50 \\
5\end{array}$ & .001 & .361 & 2.773 \\
\hline Harga & -.254 & .131 & -.239 & $\begin{array}{r}- \\
1.94 \\
6\end{array}$ & .055 & .389 & 2.573 \\
\hline $\begin{array}{c}\text { Kualita } \\
\text { s } \\
\text { Pelaya } \\
\text { nan }\end{array}$ & .454 & .075 & .495 & $\begin{array}{r}6.07 \\
0\end{array}$ & .000 & .883 & 1.132 \\
\hline
\end{tabular}

Sumber: Data diolah, SPSS 23 Tahun 2021

Hasil uji multikolinearitas pada tabel 11

dapat diketahui bahwa nilai tolerance untuk variabel promosi adalah 0,361, variabel harga adalah 0,389 dan variabel kualitas pelayanan adalah 0,883 . Jadi dapat disimpulkan bahwa nilai tolerance dari ketiga variabel lebih besar >

Nilai VIF dari variabel promosi adalah 2,773 , variabel harga adalah 2,573 dan variabel kualitas pelayanan adalah 1,132. Maka dapat disimpulkan bahwa nilai VIF dari ketigavariabel di atas lebih kecil < 10. Berdasarkan penilaian tersebut dapat disimpulkan tidak terjadi multikolinearitas antara variabel bebas.

Hasil Uji Heteroskedastisitas

Hasil uji heteroskedastisitas dapat dilihat pada tabel sebagai berikut:

Tabel 12

Hasil Uji Heteroskedastisitas 


\begin{tabular}{|c|c|c|c|c|c|}
\hline \multirow[b]{3}{*}{ Model } & \multicolumn{3}{|c|}{ Coefficientsa } & \multirow[b]{3}{*}{$\mathrm{T}$} & \multirow[b]{3}{*}{ Sig. } \\
\hline & \multicolumn{2}{|c|}{$\begin{array}{l}\text { Unstandardized } \\
\text { Coefficients }\end{array}$} & \multirow{2}{*}{$\begin{array}{c}\text { Standardize } \\
d \\
\text { Coefficients } \\
\text { Beta }\end{array}$} & & \\
\hline & B & $\begin{array}{l}\text { Std. } \\
\text { Error }\end{array}$ & & & \\
\hline (Constant) & .347 & 2.346 & & .148 & .883 \\
\hline Promosi & .031 & .096 & .054 & .320 & .750 \\
\hline Harga & .059 & .080 & .119 & .735 & .464 \\
\hline $\begin{array}{l}\text { Kualitas } \\
\text { Pelayanan }\end{array}$ & -.032 & .046 & -.076 & -.708 & .480 \\
\hline
\end{tabular}

Sumber: Data diolah, SPSS 23 Tahun 2021

Berdasarkan tabel di atas dapat

diketahui bahwa nilai signifikansi variabel

promosi sebesar $0,750>0,1$, variabel harga

sebesar 0,464 > 0,1 dan variabel kualitas

pelayanan sebasar $0,480>0,1$. Sehingga dapat

disimpulkan bahwa ketiga variabel tersebut

tidak terjadi heteroskeskedastisitas.

Hasil Analisis Regresi Linear Berganda

Analisis regresi linear berganda

digunakan untuk mengetahui pengaruh promosi (X1), harga (X2) dan kualitas pelayanan (X3) terhadap minat masyarakat (Y).

Tabel 13

Hasil Uji Analisis Regresi Linear Berganda

Coefficientsa

\begin{tabular}{|c|c|c|c|c|c|}
\hline \multirow[b]{2}{*}{ Model } & \multicolumn{2}{|c|}{$\begin{array}{c}\text { Unstandardized } \\
\text { Coefficients }\end{array}$} & \multirow{2}{*}{$\begin{array}{c}\begin{array}{c}\text { Standardized } \\
\text { Coefficients }\end{array} \\
\text { Beta }\end{array}$} & \multirow[b]{2}{*}{$\mathrm{T}$} & \multirow[b]{2}{*}{ Sig. } \\
\hline & B & $\begin{array}{l}\text { Std. } \\
\text { Error }\end{array}$ & & & \\
\hline (Constant) & $\begin{array}{r}11.65 \\
3\end{array}$ & 3.834 & & 3.039 & .003 \\
\hline Promosi & .551 & .157 & .448 & 3.505 & .001 \\
\hline Harga & -.254 & .131 & -.239 & -1.946 & .055 \\
\hline $\begin{array}{c}\text { Kualitas } \\
\text { Pelayanan }\end{array}$ & .454 & .075 & .495 & 6.070 & .000 \\
\hline
\end{tabular}

Sumber: Data diolah, SPSS 23 Tahun 2021
Berdasarkan hasil uji analisis regresi

linear berganda pada tabel 13 diatas dapat disimpulkan bahwa unstandardized coefficients tabel diatas maka persamaan regresi linear berganda dalam penelitian ini adalah:

$M M=11,653+0,551 P-0,254 H+0,454$ $\mathrm{KP}+\mathrm{e}$

Dari persamaan regresi di atas dapat diartikan bahwa:

a. Nilai konstanta $(\alpha)$ adalah sebesar 11,653 satuan dapat diartikan bahwa promosi, harga dan kualitas pelayanan diasumsikan 0, maka minat masyarakat adalah sebesar 11,653 satuan.

b. Nilai koefisien variabel promosi (b1) sebesar 0,551 dapat diartikan bahwa setiap peningkatan promosi sebesar 1 satuan, maka minat masyarakat mengalami peningkatan sebesar 0,551 satuan dengan asumsi variabel independen nilainya tetap. Koefisien bernilai positif berarti terjadi hubungan positif antara promosi dengan minat masyarakat.

c. Nilai koefisien variabel harga (b2) sebesar0,254 dapat diartikan bahwa setiap peningkatan harga sebesar 1 satuan, maka 
Purnama ${ }^{1}$, Nofinawati ${ }^{2}$, Sarmiana ${ }^{3}$, Ferri Alfadri ${ }^{4}$

minat masyarakat mengalami penurunan

sebesar 0,254 satuan dengan asumsi

variabel independen nilainya tetap.

Koefisien bernilai negatif berarti terjadi

hubungan negatif antara harga dengan

minat masyarakat.

d. Nilai koefisien variabel kualitas pelayanan

(b3) sebesar 0,454 dapat diartikan bahwa setiap peningkatan kualitas pelayanan sebesar 1 satuan, maka minat masyarakat mengalami peningkatan sebesar 0,454 satuan dengan asumsi variabel independen nilainya tetap. Koefisien bernilai positif berarti terjadi hubungan positif antara kualitas pelayanan dengan minat masyarakat.

Hasil Uji Koefisiens Determinasi (R2)

Hasil uji koefisiensi determinasi $\left(R^{2}\right)$ sebagai berikut :

Uji Tabel 14

Hasil Uji Koefisiens Determinasi (R2)

\begin{tabular}{|c|c|c|c|c|}
\hline Model & $\mathrm{R}$ & R Square & $\begin{array}{c}\text { Adjusted } \\
\text { R Square }\end{array}$ & $\begin{array}{c}\text { Std. Error of } \\
\text { the } \\
\text { Estimate }\end{array}$ \\
\hline 1 & $\begin{array}{c}.660 \\
\mathrm{a}\end{array}$ & .435 & .418 & 2.784 \\
\hline
\end{tabular}

Sumber: Data diolah, SPSS 23 Tahun 2021
POINT Vol. 2, No. 2, Des 2021

Berdasarkan tabel 14 Hasil analisis

diketahui bahwa Adjusted $\mathrm{R}$ square sebesar 0,418 atau $41,8 \%$. Hasil ini menunjukan bahwa persentase pangaruh variabel promosi, harga dan kualitas pelayanan terhadap minat masyarakat sebesar $41,8 \%$. Sedangkan sisanya sebesar 0,582 atau 58,2\% dipengaruhi oleh variabel lain yaitu variabel lain yang tidak dimasukkan dalam penelitian ini.

\section{Hasil Uji Signifikansi Parsial (Uji t)}

Uji t dalam penelitian ini digunakan untuk melihat hubungan antara variabel secara parsial. Adapun hasil uji t sebagai berikut :

Uji Tabel 15

Hasil Uji Signifikansi Parsial (Uji t)

Coefficientsa

\begin{tabular}{|c|c|c|c|c|c|}
\hline \multirow[b]{2}{*}{ Model } & \multicolumn{2}{|c|}{$\begin{array}{l}\text { Unstandardized } \\
\text { Coefficients }\end{array}$} & \multirow{2}{*}{$\begin{array}{l}\begin{array}{c}\text { Standardized } \\
\text { Coefficients }\end{array} \\
\text { Beta }\end{array}$} & \multirow[b]{2}{*}{$\mathrm{t}$} & \multirow[b]{2}{*}{ Sig. } \\
\hline & B & Std. Error & & & \\
\hline (Constant) & 11.653 & 3.834 & & 3.039 & .003 \\
\hline Promosi & .551 & . 157 & .448 & 3.505 & .001 \\
\hline Harga & -.254 & 131 & -.239 & -1.946 & .055 \\
\hline $\begin{array}{l}\text { Kualitas } \\
\text { Pelayanan }\end{array}$ & .454 & .075 & .495 & 6.070 & .000 \\
\hline
\end{tabular}

Sumber: Data diolah, SPSS 23 Tahun 2021

Untuk ttabel diperoleh dari rumus $\mathrm{df}=$ $\mathrm{n}-\mathrm{k}$ dengan jumlah responden adalah 100, jumlah seluruh variabel adalah 4 , serta tingkat kepercayaan $(\alpha)$ adalah 0,10 . Sehingga ttabel $=$ 100- $4=96$, diperoleh ttabel $=(96)=1,66088$ 
Hasil uji t dapat dilihat bahwa thitung

untuk variabel promosi sebesar $(3,505>1,66088)$ dan $(0,001<0,1)$. Jadi dapat disimpulkan bahwa promosi berpengaruh terhadap minat masyarakat Kecamatan Batang Toru menggunakan produk cicil emas di PT. Bank Syariah Mandiri KCP Batang Toru.

Hasil uji $\mathrm{t}$ dapat dilihat bahwa $\mathrm{t}_{\text {hitung }}$ untuk variabel harga sebesar $(-1,946<-$ 1,66088) dan $(0,055<0,1)$. Jadi dapat disimpulkan bahwa harga berpengaruh terhadap minat masyarakat Kecamatan Batang Toru menggunakan produk cicil emas di PT. Bank Syariah Mandiri KCP Batang Toru.

Hasil uji $\mathrm{t}$ dapat dilihat bahwa $\mathrm{t}_{\text {hitung }}$ untuk variabel kualitas pelayana sebesar $(6,070>1,66088)$ dan $(0,000<0,1)$. Jadi dapat disimpulkan bahwa kualitas pelayanan berpengaruh terhadap minat masyarakat Kecamatan Batang Toru menggunakan produk cicil emas di PT. Bank Syariah Mandiri KCP Batang Toru.

Hasil Uji Signifikansi Simultan (Uji F)

Hasil uji F digunakan untuk mengetahui pengaruh semua independen variabel terhadap dependen variabel. Adapun hasil uji F sebagai berikut :

Tabel 16

Hasil Uji Signifikansi Simultan (Uji F)

\begin{tabular}{|c|r|r|r|}
\hline \multicolumn{4}{c|}{ ANOVAa } \\
\hline Model & \multicolumn{1}{|c|}{$\begin{array}{c}\text { Sum of } \\
\text { Squares }\end{array}$} & Df & Me \\
\hline Regression & 573.271 & 3 & \\
& 744.119 & 96 & \\
Residual & 1317.390 & 99 & \\
Total & \\
\hline
\end{tabular}

Sumber: Data primer yang telah diolah, 2020

Nilai Ftabel diperoleh dengan cara $F_{\text {tabel }}$ $=(\mathrm{df} 1=\mathrm{k}-1)$ dan $(\mathrm{df} 2=\mathrm{n} \mathrm{k})$, dimana jumlah responden (n) adalah 100 dan jumlah seluruh variabel sebanyak 4 , maka $F_{\text {tabel }}=(d f 1=4-1=$ 3) dan (df2 $=100-4=96)$. Nilai $F_{\text {tabel }}$ diperoleh sebesar 2,14 dan nilai $F_{\text {hitung }}$ sebesar 24, 653 . Berdasarkan uji signifikansi simultan (uji f) pada tabel 16 di atas dapat menunjukan bahwa $F_{\text {hitung }}>F_{\text {tabel }}(24,653>2,14)$ dengan nilai signifikan 0,000< 0,1. Artinya Ha diterima. Dapat disimpulkan bahwa promosi, harga dan kualitas pelayanan berpengaruh secara simultan terhadap minat masyarakat Kecamatan Batang Toru menggunakan produk cicil emas di PT. Bank Syariah Mandiri KCP Batang Toru

Pembahasan Hasil Penelitian 
Purnama ${ }^{1}$, Nofinawati ${ }^{2}$, Sarmiana ${ }^{3}$, Ferri Alfadri ${ }^{4}$

Berdasarkan hasil analisis, maka

pembahasan hasil penelitian ini adalah sebagai berikut:

1. Pengaruh promosi terhadap minat masyarakat Kecamatan Batang Toru menggunakan produk cicil emas di PT. Bank Syariah Mandiri KCP Batang Toru

Hasil uji $t$ dapat dilihat bahwa $t_{\text {hitung }}$ untuk variabel promosi sebesar 3,505dan untuk $t_{\text {tabel }}$ diperoleh dari rumus $d f=(n-k-$ 1), $d f=(100-3-1)=96$ hasil yang diperoleh dari $t_{\text {tabel }}$ sebesar 1,66088 yang artinya $t_{\text {hitung }}$ $>t_{\text {tabel }}(3,505>1,66088)$ dan $(0,001<0,1)$, maka Ha diterima dan Ho ditolak. Jadi dapat disimpulkan bahwa promosi berpengaruh terhadap minat masyarakat Kecamatan Batang Toru menggunakan produk cicil emas di PT. Bank Syariah Mandiri KCP Batang Toru.

Jadi dapat disimpulkan bahwa semakin baik promosi yang dilakukan sebuah perusahaan maka semakin banyak masyarakat yang mengenal produk dan jasa yang ada diperusahaan tersebut. Dengan promosi yang menarik juga dapat
POINT Vol. 2, No. 2, Des 2021 maningkatkan citra perusahaan dimata para konsumennya.

2. Pengaruh harga terhadap minat masyarakat Kecamatan Batang Toru menggunakan produk cicil emas di PT. Bank Syariah Mandiri KCP Batang Totu

Hasil uji $t$ dapat dilihat bahwa $t_{\text {hitung }}$ untuk variabel harga sebesar -1,946dan hasil yang diperoleh dari $t_{\text {tabel }}$ sebesar $=$ 1,66088 yang artinya $-t_{\text {hitung }}<-t_{\text {tabel }}(-1,946$ $<-1,66088)$ dan $(0,055<0,1)$ maka $\mathrm{Ha}$ diterima dan Ho ditolak. Jadi dapat disimpulkan bahwa harga berpengaruh terhadap minat masyarakat Kecamatan Batang Toru menggunakan produk cicil emas di PT. Bank Syariah Mandiri KCP Batang Toru.

Jadi dapat disimpulkan bahwa harga berpengaruh terhadap minat. Dengan harga yang mahal akan mengurangi minat masyarakat dalam membeli suatu produk dan sebaliknya dengan harga yang murah dapat menambah minat masyarakat dalam membeli suatu produk.

3. Pengaruh kualitas pelayanan terhadap minat masyarakat Kecamatan Batang Toru 
menggunakan produk cicil emas di PT. Bank

Syariah Mandiri KCP Batang Toru.

Hasil uji t dapat dilihat bahwa $t_{\text {hitung }}$ untuk variabel kualitas pelayanna sebesar 6,070 dan hasil yang diperoleh dari $t_{\text {tabel }}$ sebesar $=1,66088$ yang artinya $t_{\text {hitung }}<t_{\text {tabel }}$ $(6,070>1,66088)$ dan $(0,000<0,1)$, maka Ha diterima dan Ho ditolak. Jadi dapat disimpulkan bahwa kualitas pelayanan berpengaruh terhadap minat masyarakat Kecamatan Batang Toru menggunakan produk cicil emas di PT. Bank Syariah Mandiri KCP Batang Toru.

Jadi dapat disimpulkan bahwa kualitas pelayanan berpengaruh terhadap minat masyarakat. Semakin baik kualitas pelayanan yang diberikan, maka dapat meningkatkan minat masyarakat untuk membeli kembali suatu produk.

4. Pengaruh promosi, harga dan kualitas pelayanan terhadap Minat Masyarakat Kecamatan Batang Toru menggunakan produk cicil emas di PT. Bank Syariah Mandiri KCP Batang Toru.

Berdasarkam tabel uji signifikansi simultan uji simultan (uji F) di atas dapat dijelaskan bahwa nilai $F_{\text {hitung }}>F_{\text {tabel }}(24,653$

$>2,14)$ dengan nilai signifikan $0,000<0,1$ artinya $\mathrm{Ha}$ diterima dan $\mathrm{Ho}$ ditolak. Dapat disimpulkan bahwa promosi, harga dan kualitas pelayanan berpengaruh secara simultan terhadap minat masyarakat Kecamatan Batang Toru menggunakan produk cicil emas di PT. Bank Syariah Mandiri KCP Batang Toru.

Jadi dapat disimpulkan bahwa promosi, harga, dan kualitas pelayanan berpengaruh terhadap minat masyarakat, yang artinya dalam meningkatkan minat masyarakat diperlukan adanya kualitas pelayanan yang baik, harga yang terjangkau, dan strategi promosi yang menarik serta didukung dengan faktorfaktor lainnya.

\section{PENUTUP}

\section{Kesimpulan}

Berdasarkan hasil analisis data dan pembahasan hasil penelitian, maka dapat diambil kesimpulan dari penelitian adalah sebagai berikut : secara parsial promosi berpengaruh terhadap minat masyarakat Kecamatan Batang Toru menggunakan produk 
Purnama ${ }^{1}$, Nofinawati ${ }^{2}$, Sarmiana ${ }^{3}$, Ferri Alfadri ${ }^{4}$

cicil emas, harga berpengaruh terhadap minat

masyarakat Kecamatan Batang Toru

menggunakan produk cicil emas, dan kualitas

pelayanan berpengaruh terhadap minat

masyarakat Kecamatan Batang Toru

menggunakan produk cicil emas di PT. Bank

Syariah Mandiri KCP Batang Toru. Sedangkan

secara simultan dapat disimpulkan bahwa

promosi, harga dan kualitas pelayanan

berpengaruh secara simultan terhadap minat

masyarakat Kecamatan Batang Toru

menggunakan produk cicil emas di PT. Bank

Syariah Mandiri KCP Batang Toru.

\section{Saran}

Semoga adanya pengetahuan masyarakat terhadap minat produk perbankan syariah

\section{DAFTAR PUSTAKA}

Abdul Nasser Hasibuan, Jurnal Imara, "Strategi pemasaran produk funding di PT. Bank pembiayaan rakyat syariah padangsidimpuan", 2018.

Ali Hardana, Jurnal Al Masharif, "Model Pengembangan Kewirausahaan Di Perguruan Tinggi”, 2018.

Abdul Azis. (2019, Oktober). Wawancara.

Achmad Rizal. (2020). Manajemen Pemasaran Di Era Masyarakat Industry 4.0. CV Budi Utama.
POINT Vol. 2, No. 2, Des 2021

Ajat Rukajat. (2018). Pendekatan Penelitian Kuantitatif. CV Budi Utama.

Budi Gautama Siregar. (2018). Pengaruh Kualitas Produk, Harga, Promosi Dan Atribut Produk Terhadap Keputusan Pembelian Pasta Gigi Pepsodent Pada Mahasiswa Jurusan Ekonomi Syariah Fakultas Ekonomi Dab Bisnis Islam lain Paadangsidimpuan. Vol. 6, No. 1. http://jurnal.iainpdangsidimpuan.ac.id/index.php/Almasharif/article/view/1438

Cut Mutiawati. (2019). Kinerja Pelayanan Angkutan Umum Jalan Raya. CV Budi Utama.

Danang Sunyoto. (2014). Dasar-Dasar Manajemen Pemasaran (Konsep, Strategi, Kasus). caps.

Darmadi. (2017). Pengembangan Model Metode Pembelajaran dalam Dinamika Belajar Siswa. CV Budi Utama.

Departemen Agama RI. (2015). AL-Qur'an dan Terjemah. Cipta Bagus Segera.

Fahmi Gunawan. (2018). Senarai Penelitian Pendidikan, Hukum dan Ekonomi Di Sulawesi Tenggara. CV Budi Utama.

Ibn Hajar Al-Asqalani. (1998). Bulughul Maram. PT Mizan Pustaka.

Jakpar hakim. (2020, Oktober). Wawancara.

Juharni. (2017). Manajemen Mutu Terpadu,. CV Sah Media.

M. Nur Rianto Al Arif. (2010). Dasar-Dasar Pemasaran Bank Syariah. alfabeta.

Maria Fitriah. (2018). Komunikasi Pemasaran Melalui Desain Visual. Deepublish Publisher.

Nana Herdiana Abdurrahman. (2013). Kewirausahan. CV Pustaka Setia. 
Nurul Huda. (2017). Pemasaran Syariah Teori \& Aplikasi. Kencana.

Oni Sahroni. (2020). Fikih Muamalah Kontemporer Jilid 3 Membahas Sosial dan Ekonomi Kekinian. Republika Penerbit.

Rodame Monitorir napitupulu. dkk. (2018). Pengaruh Kualitas Pelayanan Terhadap Kepuasan Pasien Rawat Inap di RSUD Gunung Tua Kecamatan Portibi Kabupaten Padang Lawas Utara. Attijaroh, Vol 4 No 2. https://scholar.google.co.id/citations?vi ew

Ruri Putri Utami. Dkk. (2017). Pengaruh Harga Dan Kualitas Produk Terhadap Minat Beli Sayuran Organik Di Pasar Sambas Medan. Vol. 6, No. 2. https://jurnal.unimed.ac.id/2012/index. php/niagawan/article/view/8334

Suryani, Hendryadi. (2015). Metode Riset Kuantitatif Teori Dan Aplikasi Pada Penelitian Bidang Manajemen Dan Ekonomi Islam. kencana. 